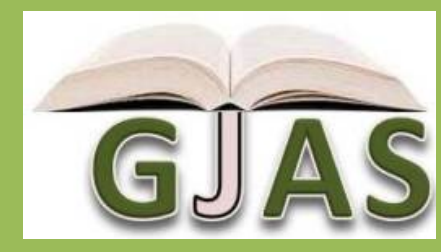

\title{
Climate Variability and Cocoa Production in Meme Division of Cameroon: Agricultural Development Policy options
}

\section{*1Jude Ndzifon Kimengsi and 2Joseph Ngong Tosam}

\author{
${ }^{1}$ Pan African Institute for Development West Africa, Buea. \\ ${ }^{2}$ Department of Economics and Management, University of Buea, Cameroon.
}

$\begin{array}{ll}\text { ARTICLE INFO } & \text { ABSTRACT }\end{array}$

Article No.: 022713505

DOI: 10.15580/GJAS.2013.8.022713505

Submitted: $27 / 02 / 2013$

Accepted: 22/08/2013

Published: 29/08/2013

*Corresponding Author

Jude Ndzifon Kimengsi

E-mail: ukjubypro2@yahoo.com

Keywords:

Climate variability, Cocoa, pests

and diseases, livelihood,

agricultural planning
This study examines the effect of climate variability on cocoa production which is the mainstay of the population of Meme Division. Meme Division stands as one of the highest cocoa producing divisions of the Cameroon. Field studies accompanied by the administration of 155 questionnaires (50 each for Kumba and Mbonge Subdivisions and 55 for Konye Subdivision) were employed. Information on climatic variables (temperature and rainfall) and cocoa output for 21 years (1990-2010) was also obtained. The data was analyzed with the use of the four point likert scale survey and the coefficient of variation (CV). The results showed that the CV for rainfall (15.1\%) and temperature (11.0\%) all exceeded the variability threshold of $10 \%$ indicating that they exhibit significant variability. Trend analysis for cocoa output shows that unusual variations were experienced in some years. This was further confirmed by the Jarque-Bera statistics of 0.68 (P-Value $=0.71$ ) which indicates that the output of cocoa is not normally distributed over time. It was also observed that the increasing unpredictability of rainfall and temperatures tend to confuse the cocoa crop and the farmers as their traditional farming calendar have been distorted; no sooner has the cocoa crop been able to adjust with the new climatic scenario than they are confronted with a different pattern. Furthermore, farmers noted a drop in cocoa output per hectare. This has led to a reduction in incomes realised giving rise to limited possibility for expansion. It is seemingly evident that their present adaptation strategies are yet to contain this ugly situation. The study suggests a number of agricultural development planning options which the government and the local population can embark on to develop a resilience framework for cocoa farmers in Meme Division in the face of expected variability in climate. 


\section{INTRODUCTION}

The economy of Cameroon experienced a recession from the mid-1980s to the early 2000s. As a result of this recession, many civil servants found solace in cash crop production, particularly cocoa since it gave room for farmers to plant food crops for subsistence and cocoa for income on the same parcel of land (mixed farming). From 2003 to 2007, the cocoa sector's contribution to Cameroon's GNP moved from $0.89 \%$ to $1.45 \%$. This accounted for between 5 to $9.652 \%$ of annual total export revenues. Cameroon currently produces 180000 tons $-5 \%$ of global production - and ranks fifth in the world in terms of cocoa production (Kumase et al., 2008). Cocoa in Cameroon is grown either through intensive or extensive production systems, or through a combination of the two. It is produced almost exclusively by family units. Cocoa production remains one of the main cash crops in Cameroon with over 600,000 people being involved in the cultivation of this crop, and over $90 \%$ of households in the cocoa producing areas of Cameroon depending on it for their income. Incomes realized depends on the price, the quantity produced, and the quality of the cocoa (UNEP, 2003). This quantity and quality of cocoa is governed, to a very large extent, by the effects of climate variability.

Cocoa thrives well in the South, Centre and South West Regions of Cameroon. Meme Division is one of the major cocoa producing divisions of the country. It is almost impossible to talk about the socioeconomic life of the inhabitants of Meme Division without making allusion to cocoa farming. This cash crop which tolerates the growing of their major staple food crops (plantains, coco yams and cassava) constitute the mainstay of the population of the division. The important role of cocoa production in this division could be clearly identified during the periods of harvest which begins from July to December. It is at this time that most business and economic operators take advantage to make money from the cocoa farmers. A local farmer concludes with the following words "cocoa season is a season of cash". Farmers however complain that their yields per hectare have been reducing over the years and their discussions, to a great extent, revolve around a number of climate related issues.

Cocoa is highly sensitive to changes in climate from hours of sun, to rainfall and application of water, soil conditions and particularly to temperature due to its effects on evapo-transpiration. This change could also alter stages and rates of development of coca pests and pathogens, modify host resistance and result in changes in the physiology of host-pathogen/pests interaction (Anim-Kwapong and Frimpong, 2005). The most likely consequences are shifts in the geographical distribution of host and pathogen/pests, altered crop yields and crop loses which will impact socio-economic variables such as farm income, livelihood and farm-level decision making (Anim-Kwapong and Frimpong, 2005).

\section{The Problem}

The caprices of weather and climate have, over the years, greatly affected the production of cocoa which is a major cash crop in Meme Division. In fact, Meme Division ranks among the highest cocoa producing divisions of Cameroon. While cocoa farmers in this division have, over the years, sought to grapple with the conventional pre and post harvest challenges facing the agricultural sector in Cameroon such as shortage of technical expertise, shortage of improved seedlings, transportation problems, marketing and other infrastructural problems, among others; they are now faced with a more precarious situation of changes in climatic elements which affect cocoa production.

Variations in the two major climatic parameters, rainfall and temperature, affect the sprouting and growth of the cocoa tree, and the production of cocoa pods. The changing weather tends to confuse the farmers and the cocoa plant. Farmers find it difficult to know when exactly to spray their crop to prevent disease and pest infection, while the crops are faced with an alteration in their normal climatic input which alters their cycle of production. These alternating climatic situations have increased the frequency and magnitude of pests and diseases affecting cocoa.

The observed variability in temperature and rainfall between 1990 and 2010 has led to variations in cocoa output resulting to a decline in yields per hectare. In addition, the coping strategies adopted by the indigenous farming population have been largely inadequate. This problem is further compounded by the fact that cocoa growing requires much investment especially in terms of time. So, this practice tends to restrict farmers from diversifying their economic activities. The absence of climatic monitoring and communication systems in Meme Division and the shortage of technical assistance, coupled with the high illiteracy levels of the majority of cocoa farmers stand to work against their possibilities of enhancing adaptation strategies to this variable climatic situation.

Going by the tenets of VISION 2035 which has as its objective the need to transform Cameroon into "An Emerging Economy by 2035" and since agriculture is the backbone of the Cameroonian economy, it is necessary to design ways of sustaining agricultural output. This study therefore evaluates the extent to which climate variability has affected cocoa production in Meme Division and suggests agricultural development policy options.

\section{Study Area}

Meme Division is located in the South West Region of Cameroon; it is one of the six divisions of the region with 
a total land area of $3.105 \mathrm{~km}^{2}$ and a total population of 326734 (BUCREP, 2010). The division lies between latitude $4^{\circ}$ and $6^{\circ}$ East of the Greenwich Meridian, and between longitude $9^{0}$ and $10^{\circ}$ north of the Equator. Meme Division consists of three sub divisions namely; Mbonge, Kumba Central and Konye Subdivisions.

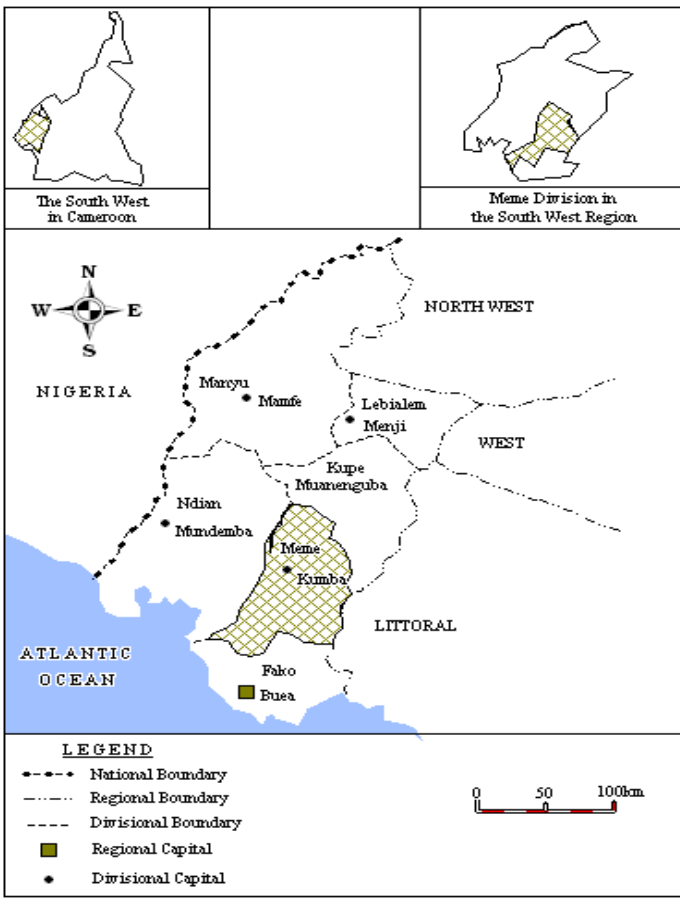

Fig. 1: Map of Meme Division Source: Adapted from Department of Surveys (Buea, 2004)

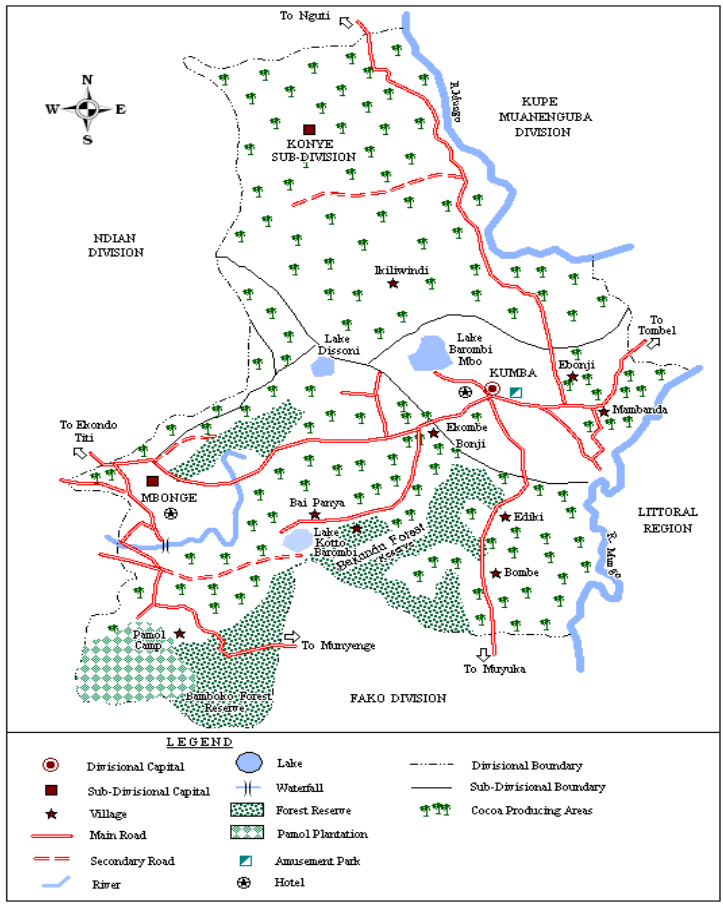

Fig.2: Spatial Distribution of Cocoa Producing Areas in Meme Division: Adapted from the BueaDouala Extract (1999)

\section{RESEARCH METHODS}

Primary and secondary sources of data were invaluable for this study. Primary data was obtained from the administration of 155 questionnaires (50 each for Kumba and Mbonge Subdivisions, and 55 for Konye Subdivision) to cocoa farmers in Meme Division. The study focused on cocoa farmers who have been engaged in the activity for at least 10 years. The questionnaire designed adopted a four point likert scale survey which had options ranging from "strongly agree" to "strongly disagree". Annual rainfall and temperature data for a 21 year period (1990-2010) came from the CDC Meteorological Station, Mukonje Rubber Estate, Kumba. The Divisional Delegation of Agriculture and Rural Development for Meme Division provided information on cocoa production for 21 years (19902010). The data obtained from the questionnaire was analyzed using the four point likert scale survey while secondary data on climatic variables was analysed using the coefficient of variation (CV). The trend analysis and the Jarque-Bera statistics which was done with the use of the E-views 3.5 package was employed in the analysis of cocoa output variations. 


\section{PRESENTATION AND ANALYSIS OF RESULTS}

Effect of Climate Variability on Cocoa Production
Farmers perception on the changes in rainfall and temperature and also their observed direction of change, that is, whether they have been increasing, decreasing or they are constant were investigated. The trend of change obtained from the four point likert scale survey is presented in Table 1 and Figure 1 (a \& b).

Table 1: Direction of Change for Rainfall and temperature

\begin{tabular}{|c|c|c|c|c|c|c|c|c|c|c|c|c|c|c|c|c|c|c|}
\hline \multirow{2}{*}{$\begin{array}{l}\text { Direction } \\
\text { of change }\end{array}$} & \multicolumn{6}{|c|}{ Increasing } & \multicolumn{6}{|c|}{ Decreasing } & \multicolumn{6}{|c|}{ Constant } \\
\hline & $\mathrm{SA}$ & $A$ & Total & $\mathrm{D}$ & SD & Total & SA & $A$ & Total & $\mathrm{D}$ & SD & Total & SA & $A$ & Total & $\mathrm{D}$ & SD & Total \\
\hline Rainfall & 41 & 30 & 71 & 5 & 1 & 6 & 17 & 45 & 62 & 5 & 2 & 7 & 0 & 4 & 4 & 0 & 5 & 5 \\
\hline Temp & 16 & 61 & 77 & - & - & - & 1 & 33 & 34 & 1 & - & 1 & 1 & 34 & 35 & 1 & 5 & 6 \\
\hline
\end{tabular}
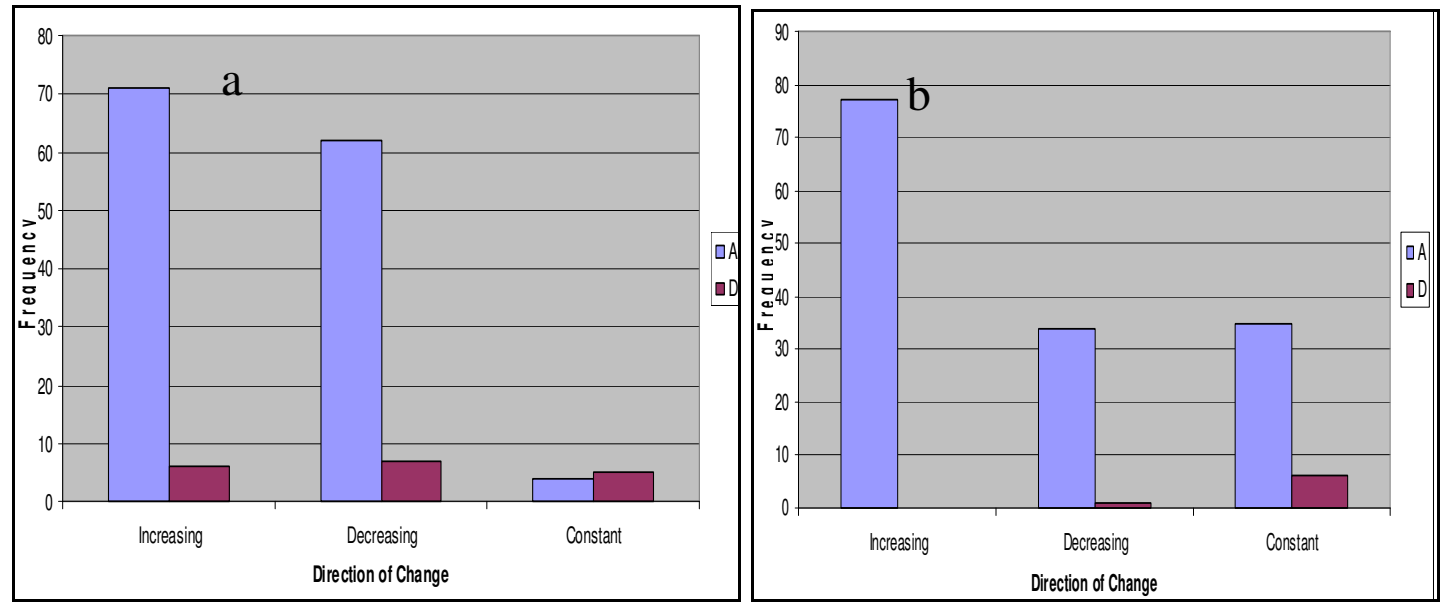

Fig. 1: Collapsed responses on the Direction of change for rainfall (a) and temperature (b) $A=$ Combined values for agree and strongly agreed $D=$ combined values for disagree and strongly disagree

Figure 1a shows that the highest frequency was obtained for farmers who agree that rainfall has been on the increase while the least was noted for those who indicated that it has remained constant. The significance of the low frequency for those who say it has been constant is that a majority of the farmers were of the opinion that there have been fluctuations in the rainfall received for the area. Similarly, Figure $1 b$ shows that the highest frequency of responses was registered for those who agreed that temperatures have been increasing. If temperatures have not been constant, then there is a likelihood that fluctuations have been registered, either through an increase or a decrease. The trend of changes in rainfall indicated that it largely begins and ends earlier or later than expected (Table 2 and Figure 2).

Table 2: Trend of Changes in rainfall in Meme Division

\begin{tabular}{|c|c|c|c|c|c|c|c|c|c|c|c|c|c|c|c|c|c|c|}
\hline $\begin{array}{l}\text { Direction } \\
\text { of change }\end{array}$ & \multicolumn{4}{|c|}{ Begins and ends earlier than } \\
expected & \multicolumn{4}{|c|}{ Begins and ends later than } & \multicolumn{5}{|c|}{ Constant } \\
\hline & SA & A & Total & D & SD & Total & SA & A & Total & D & SD & Total & SA & A & Total & D & SD & Total \\
\hline Rainfall & 30 & 47 & 77 & 4 & - & 4 & 23 & 51 & 74 & - & - & - & - & - & - & - & - & - \\
\hline
\end{tabular}

The option for constant showed no frequency. This therefore justifies the fact that the rainfall has been fluctuating. The significance of this result is that whether the rainfall begins and ends earlier or later, the bottom line is that there are fluctuations which definitely confuse the cocoa farmers and the cocoa plant itself. This has a bearing on the fluctuations in cocoa output. 


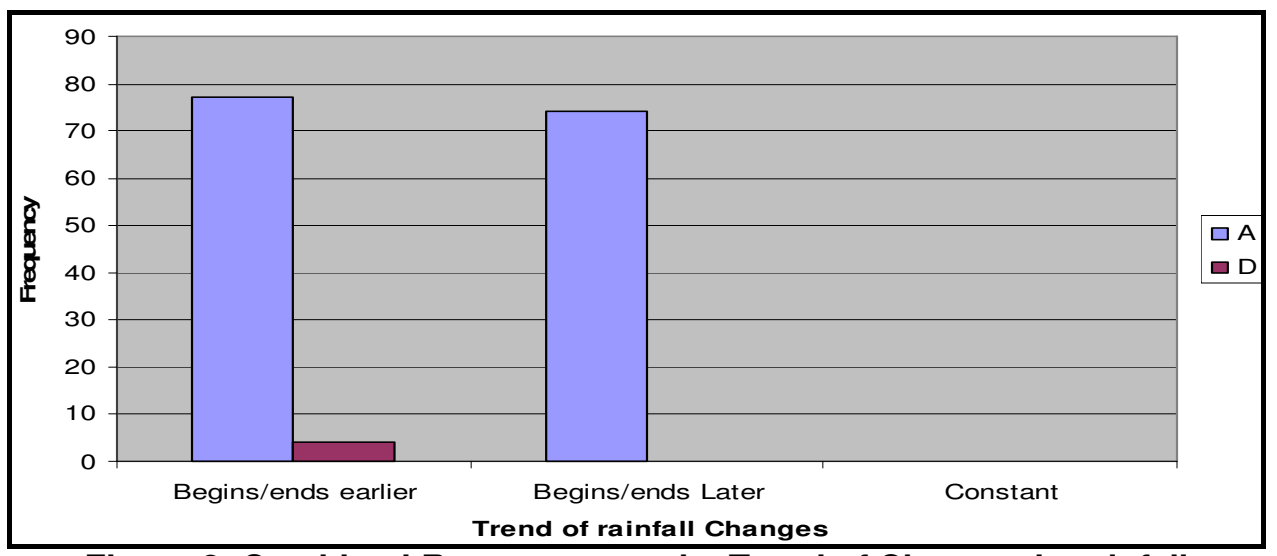

Figure 2: Combined Responses on the Trend of Changes in rainfall

The observed fluctuations in climate affects cocoa production through poor germination of the crop, early ripening and increase in cocoa disease, among others (Table 3 and Figure 3 ).

Table 3: Effects of Climate variability on Cocoa Production in Meme Division

\begin{tabular}{|l|c|c|c|c|c|c|}
\hline & SA & A & Total & D & SD & Total \\
\hline Poor germination and growth of cocoa plant & 55 & 71 & 126 & 24 & 5 & 29 \\
\hline Earlier ripening of cocoa pod (sun ripe) & 49 & 73 & 122 & 31 & 2 & 33 \\
\hline Increase in cocoa diseases & 53 & 58 & 111 & 36 & 8 & 44 \\
\hline Increase expenditure on spraying & 71 & 80 & 151 & 0 & 4 & 4 \\
\hline Reduced earnings from cocoa & 46 & 84 & 130 & 17 & 8 & 25 \\
\hline
\end{tabular}

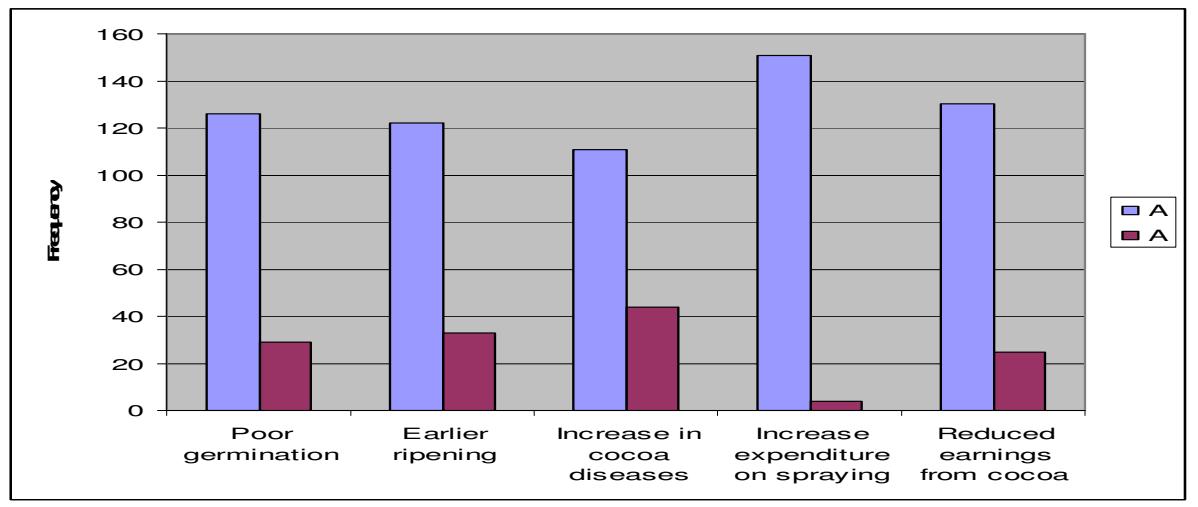

Fig. 3: Combined Responses on the Effects of Climate variability on Cocoa Production

The frequency of responses for those who agree on the various effects were all high. The highest noted was on the increase in expenditure on spraying. This therefore justifies the incidence of increase in disease and pests and the problem of re-spraying with significant losses registered.

\section{Diseases Affecting Cocoa Production in Meme Division}

The black pod disease and capsid pest were identified. It was observed that they are on the increase (Table 4 and Figure $4 \mathrm{a} \& \mathrm{~b}$ ).

Table 4: Frequency of Responses on the Changes in Cocoa Diseases

\begin{tabular}{|c|c|c|c|c|c|c|c|c|c|c|c|c|c|c|c|c|c|c|}
\hline \multirow{2}{*}{$\begin{array}{l}\text { Direction } \\
\text { of change }\end{array}$} & \multicolumn{6}{|c|}{ Increasing } & \multicolumn{6}{|c|}{ Decreasing } & \multicolumn{6}{|c|}{ Constant } \\
\hline & SA & $A$ & Total & $\mathrm{D}$ & SD & Total & SA & $A$ & Total & $\mathrm{D}$ & SD & Total & SA & $A$ & Total & $\mathrm{D}$ & SD & Total \\
\hline Black Pod & 54 & 45 & 99 & 2 & 1 & 3 & 10 & 18 & 28 & 2 & 1 & 3 & 3 & 6 & 9 & 10 & 3 & 13 \\
\hline Capsid & 39 & 54 & 93 & 1 & 2 & 3 & 9 & 21 & 30 & 6 & & 6 & 4 & 6 & 10 & 9 & 4 & 13 \\
\hline
\end{tabular}



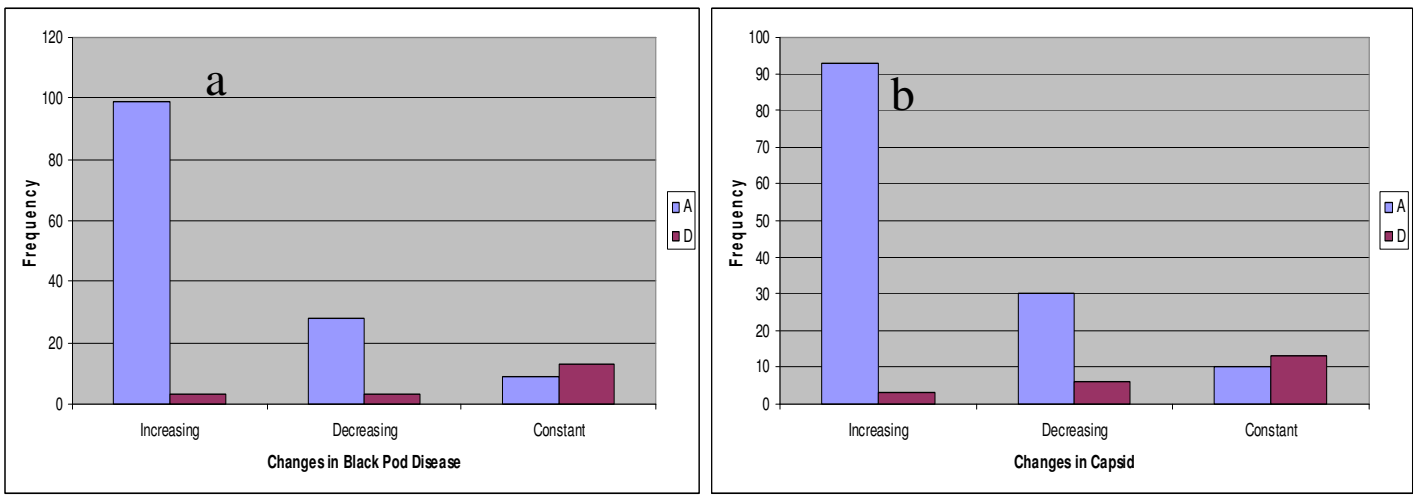

Fig. 4: Combined Frequency of Responses on the Changes in Black Pod Disease and Capsid

This justifies the fact that the increasing unpredictability of whether parameters have created a favourable environment for the breeding of the black pod diseases (Figure 5) and capsid which affects cocoa production.

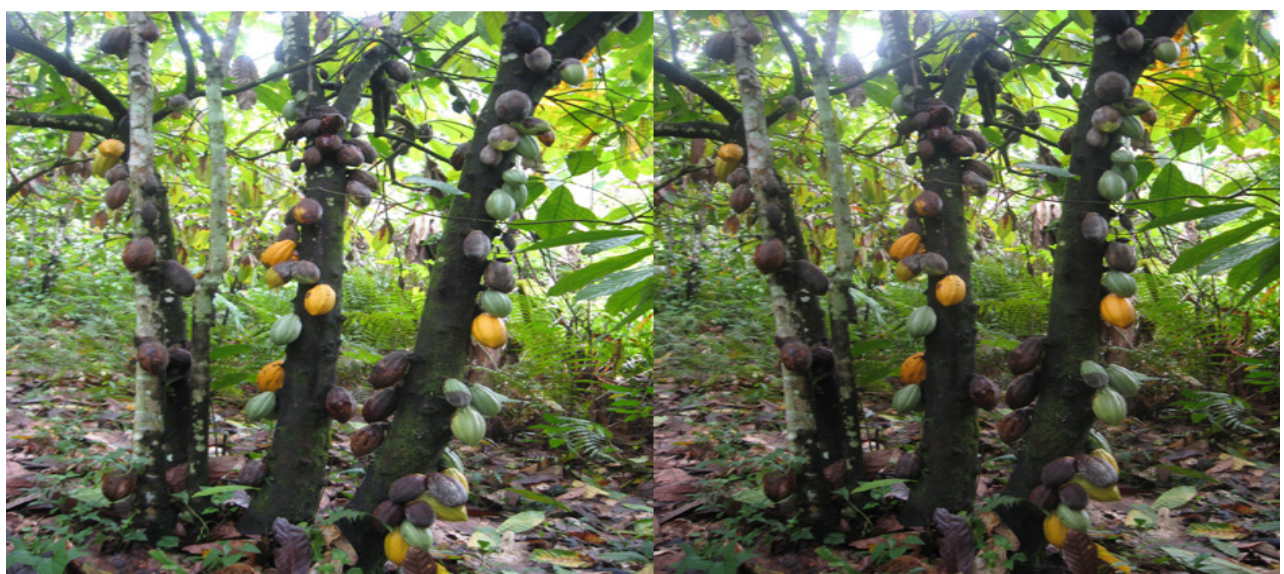

Fig. 5: Partial view of a black pod affected farm in Mbonge Subdivision (notice black cocoa pods)

\section{Variations in Climate and Cocoa Output}

The two main climatic parameters under consideration for this study are temperature and rainfall variations for the period 1991 and 2010. The data for cocoa output is presented for a 20 year period (Table 5).

Table 5: Temperature, Rainfall and Cocoa output for Meme Division (1991-2010)

\begin{tabular}{|c|c|c|c|}
\hline Years & Temperature & Rainfall & Cocoa output (tons) $^{\star}$ \\
\hline 1991 & 19.8 & 3246.2 & 15,396 \\
\hline 1992 & 21.3 & 3158.3 & 13,245 \\
\hline 1993 & 23.6 & 2971.8 & 14,321 \\
\hline 1994 & 23.2 & 2960.1 & 11,783 \\
\hline 1995 & 23.8 & 2893.4 & 12,150 \\
\hline 1996 & 24.0 & 2869.2 & 13,000 \\
\hline 1997 & 25.6 & 2936.6 & 15,256 \\
\hline 1998 & 27.4 & 2901.8 & 14,568 \\
\hline 1999 & 23.8 & 2738.9 & 22,518 \\
\hline 2000 & 22.6 & 2486.3 & 17,140 \\
\hline 2001 & 24.3 & 2434.6 & 11,986 \\
\hline 2002 & 22.6 & 2583.2 & 15,000 \\
\hline 2003 & 21.4 & 1978.0 & 6,678 \\
\hline 2004 & 23.8 & 2038.8 & 8,853 \\
\hline
\end{tabular}




\begin{tabular}{|l|c|c|c|}
\hline 2005 & 23.5 & 2156.8 & 6,589 \\
\hline 2006 & 30.4 & 1964.4 & 22,426 \\
\hline 2007 & 27.6 & 2326.1 & 21,605 \\
\hline 2008 & 23.0 & 3383.6 & 20,373 \\
\hline 2009 & 20.4 & 1924.9 & 29,715 \\
\hline 2010 & 24.2 & 2322.5 & 36,752 \\
\hline Total & 495.6 & 54301.9 & \\
\hline & Mean = 23.6 & Mean = 2585.8 \\
\hline
\end{tabular}

Source: CDC Mukonje Rubber Estate

*Annual Reports of the Divisional Delegation of MINADER,

Section of Agricultural Surveys and Statistics Meme Division, 2011

Constant fluctuations in temperatures have been observed in Meme Division. The deviations from the established threshold temperature for cocoa production show that temperature exceeds the established mean between 1990 and 1992, 1999, 2005 and 2008 (Figure 6 ). This shows variations in temperature and such shifts have a bearing on cocoa production - it provokes disease incidence and leads to premature ripening of cocoa pods. Also, significant rainfall variations have been recorded for the period 1991 to 2010 . The years 2000, 2002, 2005, 2007 and 2009 saw a marked deviation from the established rainfall threshold (Figure 7).

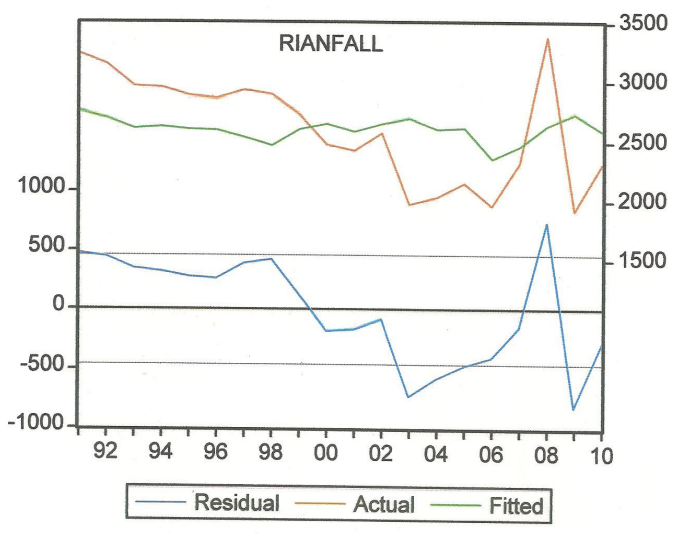

Fig. 7: Residual, actual and fitted graphs for rainfall in Meme Division

(1990-2010)

The trend analysis which reveals the period of abnormal variations in cocoa output is presented in Figure 8 . The cause of these shifts in output can be likened to variations in both rainfall and temperature because they occur in almost the same periods when these two climatic factors were above the established threshold.
These shifts alter the established agricultural calendar and distort cocoa production. These variations combined with the observed variations in temperature affect the climate sensitive cocoa crop resulting in variations in cocoa output. The output of cocoa exceeds the established threshold in 2002, 2005, 2008 and 2010. ature in Meme Division

(1990-2010) 


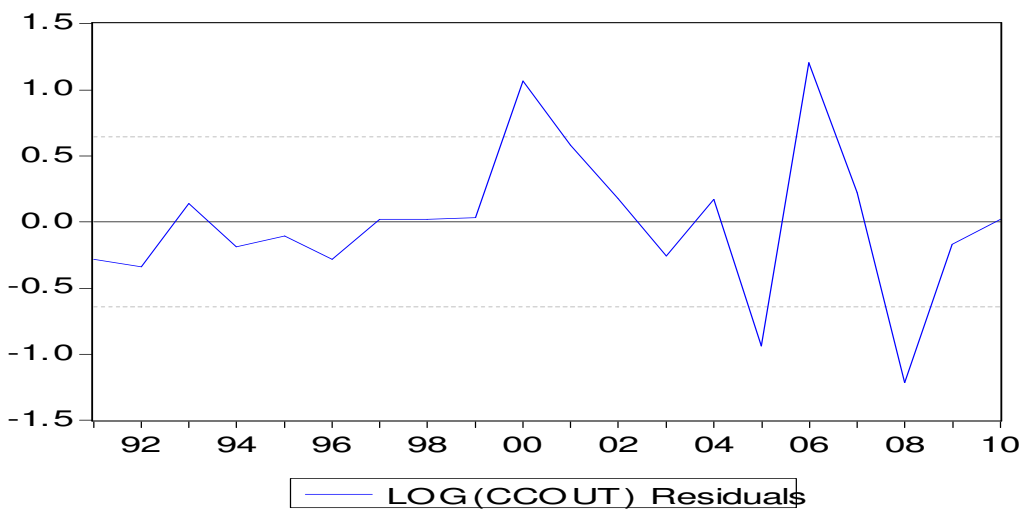

Figure 8: Trend Analysis for Cocoa output

The analyses show that unusual variations were indicating that it is not normally distributed over time. experienced in the years 2000, 2005, 2007 and 2008. To This, in turn, means that about $70 \%$ of variations in the have an apt description of the variables used in this output of cocoa is abnormally distributed and $30 \%$ is study, a descriptive statistical table was prepared (Appendix I). The table shows that the current trend in the temperature and rainfall has an average of $23.6^{\circ} \mathrm{C}$ and $2585.662 \mathrm{~mm}$ respectively. Cocoa output shows a JarqueBera statistics of 0.68 with a P-Value of 0.71 (Appendix I) normally distributed over time. Such an abnormal distribution is a clear evidence of variations in output and incomes realized from the sector. Table 6 shows a decline in output and incomes from 185,000,000 in 2005 to $151,110,000 F C F A$ in 2010.

Table 6: Changes in output and incomes from cocoa production between 2005 and 2010

\begin{tabular}{|c|c|c|c|c|c|c|c|}
\hline \multicolumn{3}{|c|}{$\mathbf{2 0 0 5}$} & \multicolumn{3}{|c|}{$\mathbf{2 0 1 0}$} \\
\hline $\begin{array}{c}\text { No of } \\
\text { Bags }\end{array}$ & $\begin{array}{c}\text { No of } \\
\text { responses }\end{array}$ & $\begin{array}{c}\text { Income/ha } \\
\mathbf{0 0 0}\end{array}$ & $\begin{array}{c}\text { Total income } \\
\mathbf{0 0 0}\end{array}$ & $\begin{array}{c}\text { No of } \\
\text { Bags }\end{array}$ & $\begin{array}{c}\text { No of } \\
\text { responses }\end{array}$ & $\begin{array}{c}\text { Income/ha } \\
\mathbf{0 0 0}\end{array}$ & $\begin{array}{c}\text { Total } \\
\text { income } \\
\mathbf{0 0 0}\end{array}$ \\
\hline $1-5$ & 8 & $<350$. & 2800 & $1-5$ & 6 & $<350$. & 2100 \\
\hline $6-10$ & 13 & $360-700$ & 6890 & $6-10$ & 34 & $360-700$ & 18020 \\
\hline $11-15$ & 37 & $710-1100$ & 33485 & $11-15$ & 68 & $710-1100$ & 61540 \\
\hline $16-20$ & 72 & $1200-1500$ & 97200 & $16-20$ & 33 & $1200-1500$ & 44550 \\
\hline $21-25$ & 21 & $1600-1850$ & 36225 & $21-25$ & 12 & $1600-1850$ & 20700 \\
\hline $25-30$ & 4 & $1900-2300$ & 8400 & $25-30$ & 2 & $1900-2300$ & 4200 \\
\hline Total & & & $185,000,000$ & & & & $151,110,000$ \\
\hline
\end{tabular}

Source: Field Estimates, 2011

\section{Rainfall and Temperature Variability}

Rainfall and temperature values have witnessed significant variability (Table 7).

Table 7: Annual Rainfall and Temperature Variability in Meme Division

\begin{tabular}{|c|c|c|c|c|c|c|}
\hline Years & $\begin{array}{c}\text { Rainfall } \\
[\mathbf{m m}] \mathbf{x}]\end{array}$ & $(x-\bar{x})$ & $(x-\bar{x})^{2}$ & $\begin{array}{c}\text { Temperature } \\
\mathbf{( x )}\end{array}$ & $x-\bar{x}$ & $(x-\bar{x})^{2}$ \\
\hline 1990 & 2023.4 & -562.4 & 316293.8 & 19.3 & -4.3 & 18.5 \\
\hline 1991 & 3246.2 & 660.4 & 436128.2 & 19.8 & -3.8 & 14.4 \\
\hline 1992 & 3158.3 & 572.5 & 32775.6 & 21.3 & -2.3 & 5.3 \\
\hline 1993 & 2971.8 & 386 & 148996 & 23.6 & 0 & 0 \\
\hline 1994 & 2960.1 & 374.3 & 140100.5 & 23.2 & -0.4 & 0.2 \\
\hline 1995 & 2893.4 & 307.3 & 94617.8 & 23.8 & 0.2 & 0.04 \\
\hline 1996 & 2869.2 & 307.6 & 80315.6 & 24.0 & 0.4 & 0.2 \\
\hline 1997 & 2936.6 & 283.2 & 123060.6 & 25.6 & 2 & 4 \\
\hline 1998 & 2901.8 & 316 & 99856 & 27.4 & 3.8 & 14.4 \\
\hline 1999 & 2738.9 & 153.1 & 23439.6 & 23.8 & 0.2 & 0.04 \\
\hline
\end{tabular}




\begin{tabular}{|c|c|c|c|c|c|c|}
\hline 2000 & 2486.3 & -99.5 & 9900.3 & 22.6 & -1 & 1 \\
\hline 2001 & 2434.6 & -151.1 & 22861.4 & 24.3 & 0.7 & 0.5 \\
\hline 2002 & 2583.0 & -2.6 & 6.8 & 22.6 & -1 & 1 \\
\hline 2003 & 2038.8 & -607.8 & 369420.8 & 21.4 & -2.2 & 4.8 \\
\hline 2004 & 2038.8 & -547 & 299209 & 23.8 & 0.2 & 0.04 \\
\hline 2005 & 2156.8 & -429 & 184041 & 23.5 & -0.1 & 0.01 \\
\hline 2006 & 1964.4 & -621.4 & 386137.0 & 30.4 & 6.8 & 46.24 \\
\hline 2007 & 2326.1 & -259.7 & 67444.1 & 27.6 & 4 & 16 \\
\hline 2008 & 3383.6 & -797.8 & 636484.8 & 23.0 & -0.6 & 0.4 \\
\hline 2009 & 9924.9 & -660.9 & 436788.8 & 20.4 & -3.2 & 10.24 \\
\hline 2010 & 2322.5 & -263.3 & 69326.9 & 24.2 & 0.6 & 0.4 \\
\hline Total & $\mathbf{5 4 3 0 1 . 9}$ & & $\mathbf{3 0 3 9 8 3 8 . 3}$ & 495.6 & & 137.7 \\
\hline & - & & - & & \\
& $x=2585.8$ & & & & &
\end{tabular}

To calculate the CV, the standard deviation is obtained. This is defined as

$\mathbf{\delta}=$ Standard Deviation

$\delta=\sqrt{\frac{\sum(x-\bar{x})^{2}}{n-1}}$

$$
\delta=\sqrt{\frac{30398383}{20}} \Rightarrow \sqrt{151991.9}=389.9
$$

C.V for rainfall $=C V=\frac{\delta}{x} X \frac{100}{1} \quad C V=\frac{389.9}{2585.8} X \frac{100}{1}=15.1 \%$

$$
\delta=\text { StandardDeviation } \quad C V=\text { Coeficient of Variation }
$$

CV for temperature $\delta=\sqrt{\frac{137}{20}} \Rightarrow \delta=\sqrt{6.9}=2.6 \quad C V=\frac{2.6}{23.6} X \frac{100}{1} \Rightarrow C V=11.0 \%$

\section{CV for temperature $=\mathbf{1 1 . 0} \%$}

Greater reliability means less variability. As a rule of thumb, when a CV is greater than 10 as shown above, it is unreliable but when the CV is less than 10 , it is reliable which means that the variability is low. Both rainfall and temperature show a marked degree of variations, having exceeded the $10 \%$ threshold of reliability. The CV for rainfall $(15.1 \%)$ and that of temperature (11.0\%) all exceed the 10\% threshold indicating that there exists significant variability in these climatic elements. The interpretation here is that such variations translate into a decline in cocoa output and income.

\section{Agricultural Development Policy Options}

Since climate variability is "an act of nature", the indigenous population only has to rely on a number of precautionary and adaptive measures in order for the cocoa sector to survive. The government, through the Ministry of Agriculture and Rural Development, in partnership with some NGOs should embark on the introduction of improved cocoa species which are more adaptive under the current and highly unpredictable climate scenario. The Institute of Agricultural Research for Development (IRAD) should be provided with the necessary funding and other material resources to enable them undertake research to introduce new cocoa breeds which can adapt to the caprices of climate and still maintain high productivity. These improved varieties should be distributed to cocoa farmers. This institute could also carry out further research in order to come up with new cocoa breeds which are more resistant to the prevailing climate and disease situation. This will reduce the losses incurred in the sector.

A short run solution to the problem of increasing cocoa pest and diseases is the granting of subsidies or free pesticide distribution to cocoa farmers. The distribution of these pesticides will help to reduce the cost of production incurred by farmers and this will encourage them to stay in the activity. In another dimension, these cocoa farmers should form cooperatives and common initiative groups and work together to obtain a collective solution to their problem, especially those of the purchase of more effective cocoa chemicals. 
The government should reduce taxes on farm inputs such as chemicals and spraying machines. It can also initiate the introduction of high quality chemicals and check supply sources to avoid the sale of poor quality chemicals. Local agencies which are charged with the duty of checking the incessant flooding of fake cocoa chemicals should be introduced. There is a need for the re-institution of the Produce Marketing Board by the government which provides chemicals to farmers at subsidized rates and makes the conditions for obtaining finances to cater for the rest of their farms very simple.

To avoid the severe effects of fluctuations in cocoa output, the farmers should be sensitized on the need to diversify cash crop production. That is, they can allocate part of their resources to the cultivation of less climate-sensitive crops like rubber and oil palm. This will spare them the shocks which accompany the total reliance on cocoa production in climate unfriendly years. Diversification of agriculture is also recommended through the planting of other food crops. Also, farmers should get involved in other income generating activities and start small businesses which could sustain their households during periods of low harvest.

It is also recommended that there should be effective maintenance of cocoa trees through pruning and maintaining the shade canopy of the trees. This is because when these trees are not pruned, they create very damp conditions which lead to the proliferation of the black pod disease especially. Pruning would therefore discourage the creation of a damp atmosphere.

With the ongoing project on the National Climate Change Monitoring Centre, it is necessary to indicate that outreach stations should be created in Meme Division, given its significant contribution to national cocoa production. This monitoring centre would collect day- to- day climate information and develop a future climate modeling picture which should be communicated to the local farmers through the media, seminars and workshops. This will enable them to plan well ahead to avoid the persistent confusion brought about by the highly unpredictable nature of climate change which leaves them at the mercy of this calamity. This will also reduce the high incidence of re-spray since daily weather reports will be communicated to the farmers in all local languages so that they should know the appropriate time to embark on spraying.

Agricultural extension workers should be trained through refresher courses, seminars and workshops on new techniques of preparing the agricultural sector to make use of the benefits introduced by climate change while developing resistance to the problems introduced by this change. The dissemination of climate related information and ways of coping with climate caprices should be the prerogative of agricultural extension workers who, unfortunately, are small in their number. Meme Division has a very limited number of these workers who are expected to comb the entire division to hold crucial discussions and teach farmers on how to adapt to this climatic situation.

In the face of expected uncertainties in climate, there is a need for the cocoa farmers to consider the need to insure their farms so that they can receive some indemnity in the event of climate related losses. This situation will help to reduce the shocks they always face in years of low yields. This study recommends the sensitization of the population on the need to insure their farms against climate related losses. Also, the government should strike a deal with insurance companies to enable them provide friendly insurance policies to these largely illiterate and highly ignorant cocoa farmers.

There is a need for the development of a good transport and infrastructural network as well as improved farm to markets roads in the highly enclaved cocoa producing areas. This will guarantee the flow of farm inputs, pesticides and improved technology to the farms on time for the improvement of the situation. The government should therefore be charged with the need to realize this project as a way of enhancing rural development.

\section{CONCLUSION}

There is strong evidence on the vulnerability of rain fed agriculture to the negative impacts of climate change and variability. Faced with such a complicated scenario which affects the livelihoods of much of the farming populations of Sub-Saharan Africa, there is need for the development of appropriate strategies to reduce the vulnerability of rain fed agriculture. This could be achieved by helping local farmers to use their local knowledge and combine it with introduced innovations to enhance local adaptations to climate change and variability (Mongi et al., 2010). An enabling environment which gives room for the smooth response to the introduction of adequate crop species as an adaptation to climate change and variability and sustaining adequate agricultural yields is needed. Essentially, the sensitivity of crop production to climate is thus a good measure of the sensitivity of the peasant household to climate variability and change (Leary, 2009). Cocoa production is a benefactor of climate and at the same time the climatic condition over which this crop is grown is subjected to consistent fluctuation in Meme Division. The increasing variability of rainfall and temperatures have had profound effect on cocoa production and the consequent economic situation of farmers in Meme Division. Based on the identified effects of variability in cocoa production and its consequent economic impact, it is necessary to stress that the policy options suggested could be very instrumental in addressing the problem of this sector which is the main source of livelihood for the population. If all these policies are effectively implemented, Meme Division will certainly remain the veritable bastion of a cocoa empire in Cameroon. 


\section{REFERENCES}

Achu C C (2009). Sustainable Cocoa Production In Southern Cameroon: Potential and Constraints of Integrated Pest Management (IPM). Conference on International Research on Food Security, Natural Resource Management and Rural Development. edTropentag 2009 University of Hamburg, October 6-8, 2009.

Amungwa FA (2010). The Social Globalisation on Coffee and Cocoa Farmers in Cameroon. African Journal of Social Sciences. 1 (1): 92-102.

Anim-Kwapong GJ \& Frimpong EB (2005). Vulnerability of Agriculture to Climate Change- Impact of Climate Change on Cocoa Production. Vulnerability and Adaptation Assessment under the Netherlands Climate Change Studies Assistance Programme Phase 2 (NCCSAP2).

Enete AA and Amusa TA (2010). Challenges of Agricultural Adaptation to Climate Change in Nigeria: A Synthesis from the Literature. INSTITUT Veolia Environment, Vol. 4, 2010.

International Food Policy Research Institute (IFPRI) (2006). How will Agriculture adapt to a Shifting Climate? In: IFPRI Forum, December 2006.

IPCC (Intergovernmental Panel on Climate Change) (2001). Climate Change 2001: the Scientific Basis. Cambridge University Press, Cambridge, UK.

Kumase WN, Bisseleua H and Klasen S (2008). Opportunities and constraints in agriculture: A gendered analysis of cocoa production in Southern Cameroon. Final draft, December 2, 2008.

Lawal JO and Emaku AL (2007). Evaluation of the Effect of Climatic Changes on Cocoa Production in Nigeria: Cocoa Research Institute of Nigeria (crin) as a Case Study. African Crop Science Conference Proceedings Vol. 8 pp. 423426. ISSN 1023-070X2007s 4.00, African Crop Science Society.

Leary $N$ (2008). Climate Change and Vulnerability: Vulnerability in Nigeria: A National Level Assessment. http://books.google.co.uk/books?. Accessed on 15/07/2011.

Mongi $H$, Majule AE and Lyimo JG (2010). Vulnerability and Adaptation of Rain Fed Agriculture to Climate Change and Variability in Semi-Arid Tanzania. African Journal of Environmental Science and Technology Vol. 4(6), pp. 371-381, June,
2010. http://www.academicjournals.org/AJEST.

ISSN 1991-637X @2010 Academic Journals. Accessed on 16/07/2011

Nelson W and Agbey SND (2005). Linkages between Poverty and Climate Change: Adaptation for Livelihood of the Poor in Ghana. Technical Paper, April, 2005.

Nhemachena C, Rashid MH \& Kurukulasuriya P (2010). Measuring the Economic Impact of Climate Change on African Agricultural Production Systems. Climate Change Economics, Vol. 1, No. 1, pp. 35-55, May 2010 University of Pretoria.

Odingo RS (2008). Climate Change and Economic Development - Issues, Challenges and Opportunities for Africa in the Decades Ahead. In African Economic Research Consortium, AERC (2008): Climate Change and Economic Development in Sub Saharan Africa. Senior Policy Seminar X, Addis Ababa, Ethiopia, 7-9 April, 2008

Ojo AD \& Sadiq I (2010). Effect of Climate Change on Cocoa Yield: A Case of Cocoa Research Institute (CRIN) Farm, Oluyole Local Government Ibadan Oyo State. Journal of Sustainable Development in Africa, Volume 12, No.1, 2010. ISSN: 1520-5509. http://jsdafrica.com/Jsda/V12NO1_Spring2010_A/P DF/Effectf. Accessed on 15/07/2011

Oyekale AS, Bolaji MB and Olowa OW (2009). The Effects of Climate Change on Cocoa

Production and Vulnerability Assessment in Nigeria. Agricultural Journal 4 (2): 77-85, 2009.

MEDWELL PUBLISHING ISSN: 1816-9155. http://www.medwelljournals.com/fulltext/?doi=aj.200 9.77.85. Accessed on 15/07/2011.

Oyekale AS (2009). Climatic Variability and its Impacts on Agricultural Income and Households' Welfare in Southern and Northern Nigeria. Electronic Journal of Environmental, Agricultural and Food Chemistry. ISSN: $1579-4377$.

Tosam JN (2011). The Economic Impact of Climate Variability on Cocoa Production in Meme Division of Cameroon. Unpublished M.Sc. Thesis, Department of Economics and Management, University of Buea, Cameroon.

United Nations Environmental Programme (UNEP) (2000). Integrating Adaptation to Climate Change into UNEP Programming. Nairobi, Kenya 8-9 April 2000 UNEP 


\section{Appendix I}

Measures of Central Tendency

\begin{tabular}{|l|c|c|c|c|c|c|}
\hline & CCOUT & LAB & KAP & TEM & RAINF & CCPP \\
\hline Mean & 16397.81 & 124025.0 & 6814592. & 23.60000 & 2585.662 & 781.1905 \\
\hline Median & 15000.00 & 122425.0 & 7569600. & 23.60000 & 2583.200 & 750.0000 \\
\hline Maximum & 36752.00 & 137360.0 & 9226700. & 30.40000 & 3383.600 & 1150.000 \\
\hline Minimum & 6589.000 & 114188.0 & 4657500. & 19.30000 & 1924.900 & 510.0000 \\
\hline Std. Dev. & 7248.041 & 7269.638 & 1732086. & 2.623357 & 462.1788 & 195.5051 \\
\hline Skewness & 1.184252 & 0.573565 & 0.011637 & 0.708639 & 0.005957 & 0.180284 \\
\hline Kurtosis & 4.368658 & 2.026722 & 1.239720 & 3.688893 & 1.720609 & 1.945698 \\
\hline & & & & & & \\
\hline Jarque-Bera & 6.547660 & 1.980282 & 2.711737 & 2.172844 & 1.432361 & 1.086366 \\
\hline Probability & 0.037861 & 0.371524 & 0.257723 & 0.337422 & 0.488615 & 0.580896 \\
\hline & & & & & & \\
\hline Observations & 21 & 21 & 21 & 21 & 21 & 21 \\
\hline Source:
\end{tabular}

Source: Computed by the Author (2010) with the aid of E-views 3.5

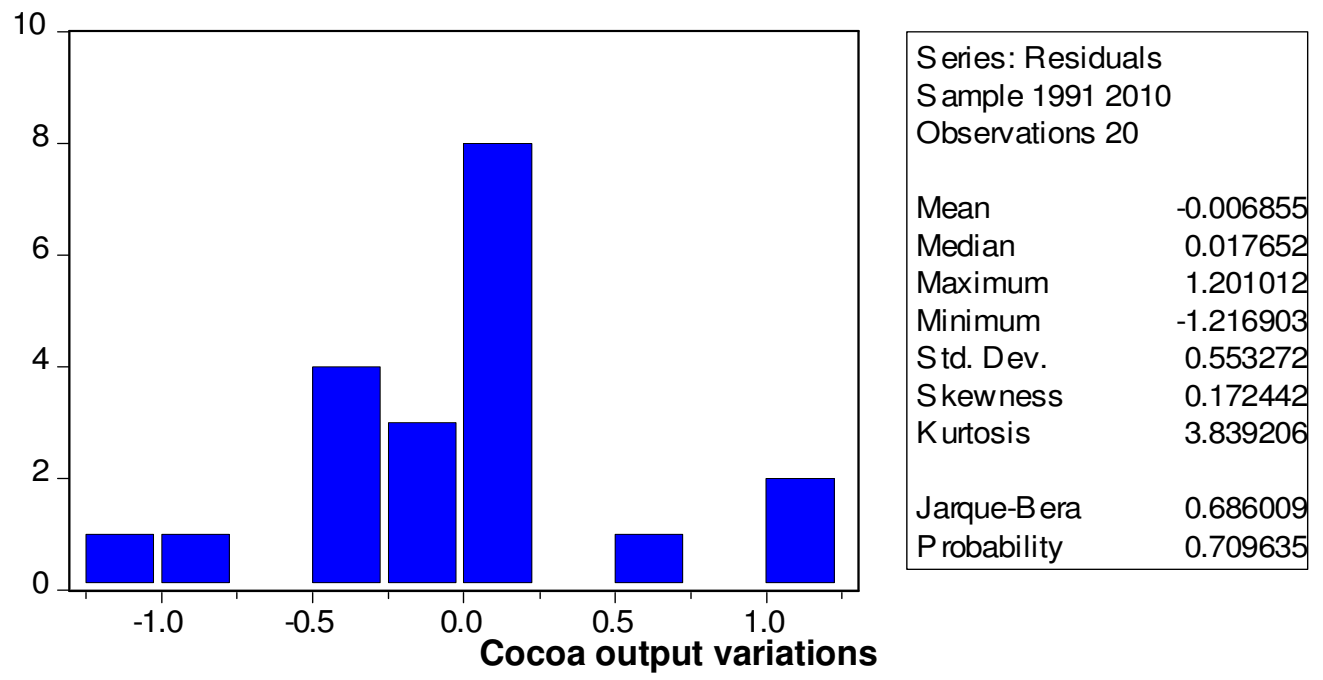

